\title{
Assessment of Technological Capabilities for Forming Al-C-B System Coatings on Steel Surfaces by Electrospark Alloying Method
}

\author{
Bogdan Antoszewski ${ }^{1}$, Oksana P. Gaponova ${ }^{2}{ }^{\circledR}$, Viacheslav B. Tarelnyk ${ }^{3}{ }^{\circledR}$, Oleksandr M. Myslyvchenko $^{4}(\mathbb{D}$, \\ Piotr Kurp ${ }^{1, *}$, Tetyana I. Zhylenko ${ }^{2}$ and Ievgen Konoplianchenko ${ }^{3} \mathbb{1}$ \\ 1 Laser Research Centre, Faculty of Mechatronics and Mechanical Engineering, Kielce University of Technology, \\ Al. Tysiąclecia P.P. 7, 25-314 Kielce, Poland; b.antoszewski@tu.kielce.pl \\ 2 The Department of Applied Material Science and Technology of Constructional Materials, \\ Sumy State University, R. Korsakov Str., 2, 40007 Sumy, Ukraine; gaponova@pmtkm.sumdu.edu.ua (O.P.G.); \\ t.zhylenko@phe.sumdu.edu.ua (T.I.Z.) \\ 3 Technical Services Department, Sumy National Agrarian University, H. Kondratiieva Str., 160, \\ 40021 Sumy, Ukraine; tarelnyk@ukr.net (V.B.T.); yevhen.konoplianchenko@snau.edu.ua (I.K.) \\ 4 Department of Physical Chemistry of Inorganic Materials, Frantsevich Institute for Problems of \\ Materials Science, Krzhizhanovsky Str. 3, 03142 Kyiv, Ukraine; zvyagina47@gmail.com \\ * Correspondence: pkurp@tu.kielce.pl
}

check for updates

Citation: Antoszewski, B.; Gaponova, O.P.; Tarelnyk, V.B.; Myslyvchenko, O.M.; Kurp, P.; Zhylenko, T.I.; Konoplianchenko, I. Assessment of Technological Capabilities for Forming Al-C-B System Coatings on Steel Surfaces by Electrospark Alloying Method.

Materials 2021, 14, 739.

https://doi.org/10.3390/ma14040739

Academic Editor: Helmut Riedl

Received: 10 December 2020

Accepted: 1 February 2021

Published: 5 February 2021

Publisher's Note: MDPI stays neutral with regard to jurisdictional claims in published maps and institutional affiliations.

Copyright: (c) 2021 by the authors. Licensee MDPI, Basel, Switzerland. This article is an open access article distributed under the terms and conditions of the Creative Commons Attribution (CC BY) license (https:// creativecommons.org/licenses/by/ $4.0 /)$.
Abstract: In this paper, the possibility of applying the electrospark alloying (ESA) method to obtain boron-containing coatings characterised by increased hardness and wear resistance is considered. A new method for producing such coatings is proposed. The method consists in applying grease containing aluminium powder and amorphous boron to the surface to be treated and subsequently processing the obtained surface using the ESA method by a graphite electrode. The microstructural analysis of the Al-C-B coatings on steel C40 showed that the surface layer consists of several zones, the number and parameters of which are determined by the energy conditions of the ESA process. Durametric studies showed that with an increase in the discharge energy influence, the microhardness values of both the upper strengthened layer and the diffusion zone increased to $\mathrm{W}_{\mathrm{p}}=0.13 \mathrm{~J}$, $\mathrm{H} \mu=6487 \mathrm{MPa}$, and $\mathrm{W}_{\mathrm{p}}=4.9 \mathrm{~J}, \mathrm{H} \mu=12350 \mathrm{MPa}$, respectively. The results of $\mathrm{X}$-ray diffraction analysis indicate that at the discharge energies of 0.13 and $0.55 \mathrm{~J}$, the phase composition of the coating is represented by solid solutions of body-centred cubic lattice (BCC) and face-centred cubic lattice (FCC). The coatings obtained at $\mathrm{W}_{\mathrm{p}}=4.9 \mathrm{~J}$ were characterised by the presence of intermetallics $\mathrm{Fe}_{4} \mathrm{Al}_{13}$ and borocementite $\mathrm{Fe}_{3}(\mathrm{CB})$ in addition to the solid solutions. The X-ray spectral analysis of the obtained coatings indicated that during the electrospark alloying process, the surface layers were saturated with aluminium, boron, and carbon. With increasing discharge energy, the diffusion zone increases; during the ESA process with the use of the discharge energy of $0.13 \mathrm{~J}$ for steel C40, the diffusion zone is $10-15 \mu \mathrm{m}$. When replacing a substrate made of steel C40 with the same one material but of steel C22, an increase in the thickness of the surface layer accompanied by a slight decrease in microhardness is observed as a result of processing with the use of the ESA method. There were simulated phase portraits of the Al-C-B coatings. It is shown that near the stationary points in the phase portraits, one can see either a slowing down of the evolution or a spiral twisting of the diffusion-process particle.

Keywords: electrospark alloying; coatings; microhardness; continuity; roughness; structure; X-ray diffraction analysis; $X$-ray spectral analysis

\section{Introduction}

Most critical parts of compressors, pumps, gas transfer apparatuses, and other dynamic equipment (DE) operate at high speeds, pressures, and temperatures, and under abrasive and corrosive conditions, or exposure to other types of working environments. 
Usually, the problems associated with improving the reliability and durability of those parts are solved through the use of expensive and high-hardness materials. In [1], it was shown that in high-speed pumps and high-pressure compressors, non-contact type mechanical seals are widely used, whose sealing rings are made entirely of wear-resistant materials such as tungsten carbide, silicon carbide, and various types of graphite. The cost of the rings made of these materials reaches hundreds and thousands of US dollars, with the attendant high cost of the sealing units as a whole [2]. Being accompanied by an increase in operating parameters of the $\mathrm{DE}$, the development of technology entails the need for the appearance of new and cheaper but no less reliable composite materials that combine the protective properties of the coatings with the mechanical strength of the substrate. Therefore, investigations aimed at creating such materials as a "base-coating" type are relevant and timely.

Surface engineering has a large number of technologies allowing the formation of the surface layers with special properties. In industry, among the most widely used methods is chemical and thermal treatment (CTT); of particular note is the use of traditional technologies such as carburising, nitriding, and nitrocarburising, which are associated with their sufficient coverage of studies and relative simplicity. It should be noted that such CTT methods as chromising, boriding, aluminising, and their combinations (carboboriding, borochromising, boroaluminising, etc.), despite the fact that they often significantly surpass traditional methods, are less in demand by technologists and heat-treaters. Their application is often limited by insufficient knowledge of the process technology, a lack of prediction of the final result (structure, hardness, warpage, residual stresses, etc.), and higher operational equipment requirements for the necessary equipment, sometimes associated with increased cost, etc. [3,4]. Boriding is one of the most effective processes for increasing the wear resistance of steel parts. As shown in [5-8], it is carried out by the CTT method including a diffusion saturation procedure in powders, gas media, molten salts, and electrolyte melts. Each of them has its own advantages and disadvantages. According to the authors of [9], among the existing boriding processes, taking into account their technological advantages and disadvantages, namely productivity (saturation rate) and cost (economic efficiency), the most preferred process is electrolysis borating, which in comparison with solid borating in powders requires neither special preparatory work nor preparation of powder mixtures. The introduction of the boriding process was carried out by firms: Degussa, Leybold Durferrit, Sandvik AB, Stahlwerke Röchling-Burbach, HEF, and others [9]. Using the boriding procedure, it is possible to achieve an increase in wear resistance by 3-50 and 1.5-15 times in comparison with heat treatment and traditional CTT methods, respectively [10]. In addition, diffusion boriding up to 5 times increases the heat resistance of steels [3]. Boride coatings have the highest wear resistance together with good heat and corrosion resistance in comparison with widely used nitriding and carburising practices. Despite the indisputable advantages of the boriding process carried out by the CTT method that makes it possible to increase surface layer hardness, wear resistance, corrosion resistance, etc., the possibility of a surface layer embrittlement cannot be excluded, which is the main disadvantage of the boride layers. In [11], it is stated that the increased fragility and tendency to form cracks and chips are explained by the anisotropy of the thermal expansion of the boride phases $\left(\mathrm{FeB}\right.$ and $\left.\mathrm{Fe}_{2} \mathrm{~B}\right)$. The absolute values of the thermal expansion coefficients of the diffusion layer phases as well as the basics and the natures of their changes depending on temperature values affect the size and distribution of the temporal and residual stresses by the layer depth. The solution to the problem of reducing the embrittlement of the boride layer can be carried out in various ways, including alloying it, performing a diffusion layer with a maximum $\mathrm{Fe}_{2} \mathrm{~B}$ phase content, and providing the formation of a single-phase layer. As a result of brittleness studies of the layers performed on the base of refractory metal borides (of titanium, vanadium, chromium, and tungsten) obtained by the synthesis of the corresponding oxides in a vacuum using electron-beam heating (electron-beam boriding) [12,13], it has been found that a process for forming refractory metal borides (of titanium, vanadium, chromium, and tungsten) in a layer applied can reduce its brittleness and increase the ductility thereof. A large number of modern 
studies have been dedicated to finding solutions for obtaining high-quality boride coatings by improving technology [14], as well as the composition of the boride coating [15,16].

Alternative technologies for producing the boride coatings, which have none of the inherent disadvantages of the CTT (process time, low productivity, the need to heat the entire workpiece, deformation and warping, the need for expensive equipment, etc.), are the boriding methods using concentrated energy fluxes (CEFs) [17-20]. In [21], a method is proposed for electroerosive boriding including applying a boron-containing surface coating by an electrode made in the form of a rod blown with a cooler. Ferroboron is used as a boron-containing electrode, and compressed air or a neutral gas is used as a cooler.

The application of local surface treatment procedures based on the method of electrospark alloying (ESA) would make it possible to obtain the layers with the desired properties. The ESA method advantages are locality, low energy consumption, the absence of volumetric heating of the material, high adhesion of the coating with the base metal, the ease of automation of the process, environmental safety, and economy [22,23]. The ESA method allows for providing the implementation of the CTT processes such as carburising, aluminising, and chromising. Additionally, with the ESA method, not only the elements of the conductive material of the anode (consisting of, for example, metal or graphite) but also dielectrics (for example, sulphur, boron, etc.) can be introduced into the surface of the part by putting them into the liquid micro-bath formed when local electric spark discharges occur. We have shown that the alloying procedure performed by the elements during the ESA process can be accomplished by creating a special technological environment (STE) without the use of expensive electrode materials and with a reduction in the time for obtaining a coating, thereby increasing productivity and cutting production costs. This can likewise be done for processes such as sulphidising [24], sulfocarburising, sulfoalitising [25], and complex coatings [26]. While considering the ESA process, it becomes clear that an important role is played by the method for thermodynamic modelling of coating synthesis, which makes it possible to evaluate the interaction products profile in the multiphase multicomponent systems [27].

The physical nature of the electrospark process performed with the influence of energy fluxes is a complex of complicated mechanical, physical, and chemical processes occurring on the contact surface in the volume of the work piece surface layer. These processes are associated with such phenomena as deformation, friction, physicochemical transformations, adhesive events, heat transfer, energy dissipation, cavitation, wave processes, material wear and tear, etc. They have a significant impact on the work piece, and as a whole, lead to a qualitatively new behaviour of the technological system (TS). The ESA processes are the complex TSs wherein there are possible self-organising processes. In the scientific literature, there is a relatively small number of works devoted to the study of CEF processing in terms of synergetics. Among the few papers, it is worth noting [28-30], wherein the mechanisms of evolution and self-organisation in the interconnected and interdependent physical processes accompanying the surface treatment procedures are examined. An analysis of those works makes it possible to draw a conclusion, on the one hand, about the prospects for studying CEF processing in terms of synergetics and, on the other hand, about insufficient knowledge of the mechanisms of self-organisation and evolution in the TS for CEF processing, especially relative to the ESA method. Despite the positive results achieved by the synergetic approach to such processes, to date there is no single theory that comprehensively describes the processes of self-organisation in the TS of the spark alloying method.

When analysing the ESA processes, a researcher has to deal with a complex physical system, which is characterised by dynamic and stochastic components that lead to self-organisation. It is possible to predict its behaviour through the use of the modified Lorentz system, which is intended for work with such components [31]. It is a common fact [32] that the Lorentz system consists of a field, an order parameter, and a control parameter. Using the modified Lorenz system, it is possible to optimise and predict the quality characteristics and the parameters of the coatings. The conditions under which 
the processes that determine the ESA procedures occur are non-equilibrium. The author of [33], as well as those of [34], have shown that in these cases, there may be present such phenomena as alloying electrode erosion, development of anode mass flow, the coating formation, and the formation of an altered surface layer. Therefore, it is relevant to apply the synergistic laws to the ESA procedures based on the study of phase transitions of the process dynamic components using the phase plane method.

The aim of this work is to improve the quality and environmental safety of the boron technology through the development of a new method for producing Al-C-B system coatings with the use of the ESA method; through studying the process of a surface layer structure and phase formation, depending on the energy parameters of the equipment used; and through studying the kinetics of the process for the surface layer formation on a steel substrate using the phase plane method.

\section{Methodology}

Samples of steel C22 and steel C40 (METINVEST HOLDING LLC, Mariupol, Ukraine) with dimensions of $15 \times 15 \times 8 \mathrm{~mm}$ were used. To the samples there was applied a grease consisting of mineral paste as a binder; PAD-0 (Dnepr-titan, Dnipro, Ukraine) grade aluminium powder, $56 \%$ by weight; and boron amorphous powder (Ukrsplav LTD, Dnipro, Ukraine) of about $5 \%$ by weight. Without waiting for the drying of the mineral paste, the surfaces of the samples were processed using the ESA method with the EG-4 (TK PROMEL, Kyiv, Ukraine) grade graphite electrode at the Elitron-52A model unit, applying a discharge energy of $0.13,0.55$, and $4.9 \mathrm{~J}$.

The surface roughness after processing was determined with the use of the 201 model of profilograph profilometer manufactured at the Caliber plant by reading and processing the profilograms. The metallographic analysis of the coatings was carried out using the Neophot-21 optical microscope (Carl Zeiss AG, Oberkochen, Germany).

Microhardness testing was performed using the PMT-3 instrument (LOMO, St. Petersburg, Russia) according to standard methods (GOST 9450-76). The test load was $50 \mathrm{~g}$. The quantitative assessment of the experimental data of microhardness measurement was carried out by the methods of mathematical statistics. The normal distribution of microhardness of a series of samples hardened in the same mode was checked. The reproducibility of the experimental results was checked using Cochran's criterion. Thus, a series of samples was investigated, and hardness measurements were carried out in several fields of a microsection. The microhardness distribution is the result of the processed data. The photos of microstructures (Section 3) show that all zones of the obtained coatings were measurable. The applied load did not lead to deformation or strengthening of the adjacent indentation area by cold work.

To study the distribution of the elements by the depth of the layer, a local X-ray microanalysis was performed. Used in doing so was the scanning electron microscope model SEO-SEM Inspect S50-B equipped with the energy dispersive spectrometer model AZtecOne with the X-MaxN20 detector (Oxford Instruments plc, Abingdon-on-Thames, $\mathrm{UK}$ ). The $\mathrm{X}$-ray investigations were carried out in $\mathrm{CoK} \alpha$ radiation using the DRON-UM1 diffractometer (voltage and current of $35 \mathrm{kV}$ and $30 \mathrm{~mA}$, respectively (Burevestnik, St. Petersburg, Russia). The diffraction patterns were read by the step-by-step scanning method. The scanning step was 0.050 , and the exposure time at a point was $3 \mathrm{~s}$.

The diffraction patterns were processed using the program for the full-profile analysis of X-ray spectra from the mixture of the PowderCell 2.4 polycrystalline components.

\section{Results and Discussions}

The research results indicate that the microstructure of the Al-C-B coatings consists of several zones, the number and parameters of which are determined by the energy conditions of the ESA process (Figure 1). At relatively low discharge energies ( 0.13 and $0.55 \mathrm{~J}$ ), the layers consist of 3 zones. Those are the upper "white" strengthened layer, the diffusion zone, and the base metal, that is, steel C40 with a ferrite-pearlite structure (Figure 1a,b). Moreover, the size of the "white" layer for the above modes was 15-20 $\mu \mathrm{m}$ 
(Table 1). The increase of the discharge energy up to $4.9 \mathrm{~J}$ led to a change in the number of zones and their structures (Figure 1c): the upper layer with a dendritic structure (up to $60 \mu \mathrm{m}$ ); the sublayer (up to $20 \mu \mathrm{m}$ ); and the diffusion zone characterised by improved structural components. In this regard, it had an increased etchability in a reagent as well as the base material.

Durametric studies showed that with an increase in the discharge energy, the microhardness of both the upper strengthened layer and the diffusion zone increased (Figure 2), at $\mathrm{W}_{\mathrm{p}}=0.13 \mathrm{~J}, \mathrm{H} \mu=6487 \mathrm{MPa}$, and at $\mathrm{W}_{\mathrm{p}}=4.9 \mathrm{~J}, \mathrm{H} \mu=12350 \mathrm{MPa}$ (Table 1), respectively.

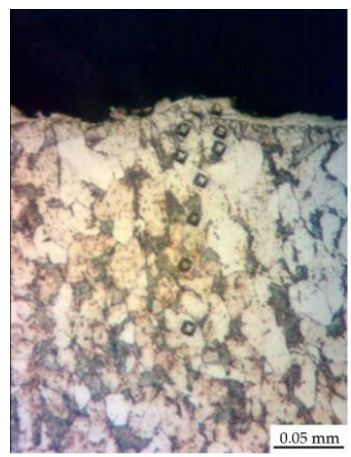

(a)

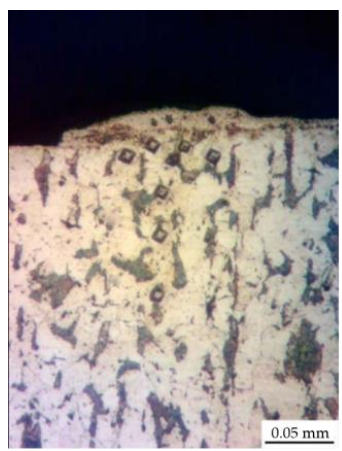

(b)

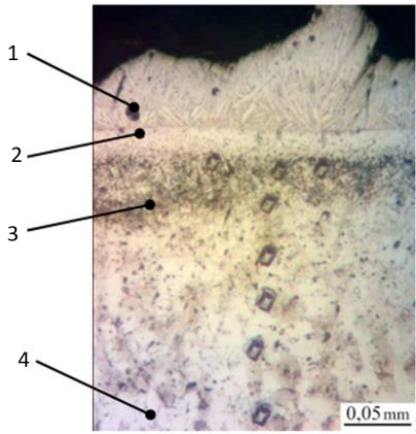

(c)

Figure 1. Microstructures of the Al-C-B coatings on steel C40: (a) $\mathrm{W}_{\mathrm{p}}=0.13 \mathrm{~J}$; (b) $\mathrm{W}_{\mathrm{p}}=0.55 \mathrm{~J} ;(\mathbf{c}) \mathrm{W}_{\mathrm{p}}=4.9 \mathrm{~J}$. The following zones can be identified: 1.- “white" layer, 2.-sublayer, 3.- diffusion zone, 4.- base material.

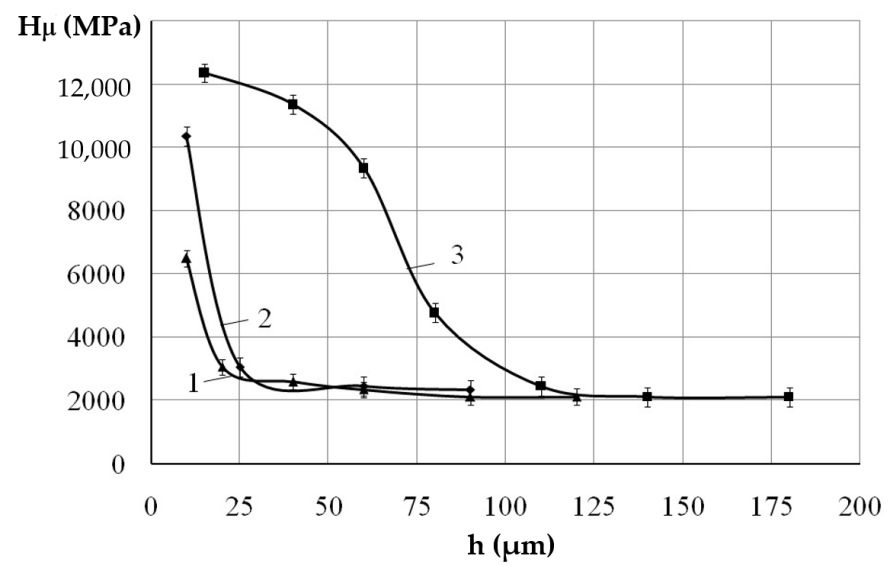

Figure 2. Microhardness distribution of the Al-C-B coatings on steel C40: (1) $\mathrm{W}_{\mathrm{p}}=0.13 \mathrm{~J}$, (2) $\mathrm{W}_{\mathrm{p}}=0.55 \mathrm{~J}$, (3) $\mathrm{W}_{\mathrm{p}}=4.9 \mathrm{~J}$.

Table 1. Qualitative parameters of Al-C-B coatings obtained by the ESA method.

\begin{tabular}{|c|c|c|c|c|c|c|}
\hline \multirow{2}{*}{ Discharge Energy, J } & \multicolumn{3}{|c|}{ Roughness, $\mu \mathrm{m}$} & \multicolumn{3}{|c|}{ Strengthened Layer } \\
\hline & $\mathbf{R a}$ & $\mathbf{R z}$ & $\operatorname{Rmax}$ & $\mathrm{H} \mu, \mathbf{M P a}$ & $h, \mu \mathrm{m}$ & $S, \%$ \\
\hline \multicolumn{7}{|c|}{ Steel C40 } \\
\hline 0.13 & 1.2 & 2.9 & 7.4 & 6487 & 15 & 55 \\
\hline 0.55 & 2.9 & 4.5 & 17.3 & 10351 & 20 & 75 \\
\hline 4.9 & 9.3 & 19.5 & 48.2 & 12350 & 60 & 95 \\
\hline \multicolumn{7}{|c|}{ Steel C22 } \\
\hline 0.13 & 1.1 & 2.7 & 7.2 & 5474 & 20 & 60 \\
\hline 0.55 & 2.9 & 4.1 & 16.3 & 10196 & 30 & 80 \\
\hline 4.9 & 8.9 & 18.7 & 46.1 & 11345 & 75 & 95 \\
\hline
\end{tabular}

S,\%-layer structural integrity. 
The results of X-ray diffraction analysis presented in Figure 3 indicate that at relatively low discharge energies $(0.13$ and $0.55 \mathrm{~J})$, the phase composition of the coatings is represented by solid solutions of BCC (body-centred cubic lattice) and FCC (face-centred cubic lattice) with the parameter of $\mathrm{a}=28.651 \mathrm{~nm}$ and $36.189 \mathrm{~nm}$, respectively (Table 2). Therefore, it can be assumed that while steel C40 is saturated with $\mathrm{Al}, \mathrm{C}$, and B by the ESA method, as a result of mixing the base material, the mineral paste containing aluminium powder, the electrode material, and graphite, the BCC solid solution is alloyed and its parameter increases. In addition, accelerated cooling after the ESA process leads to the formation of thermal stresses, resulting in additional increase in the microhardness of the coating.

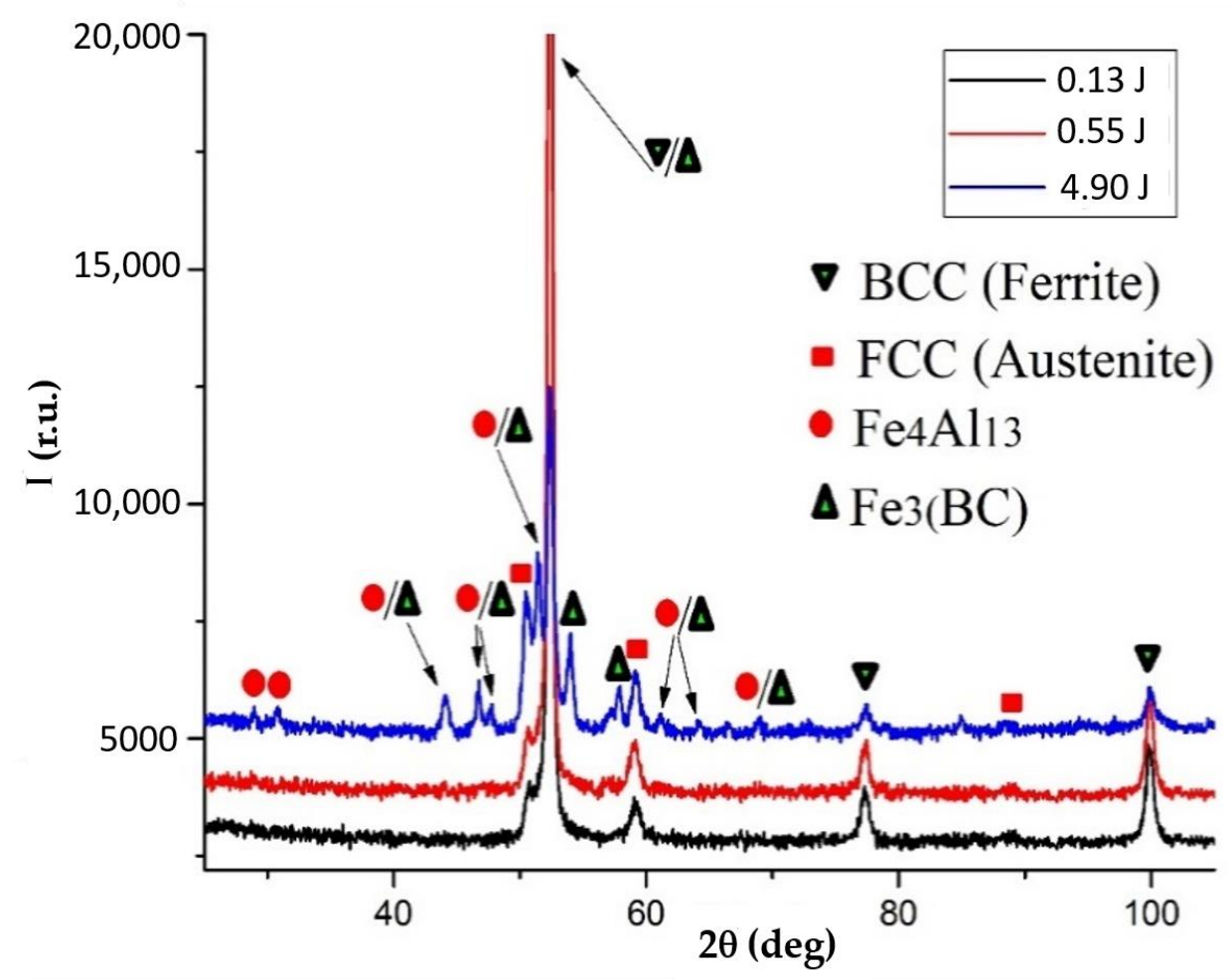

Figure 3. Diffraction patterns of Al-C-B coatings obtained by the electrospark alloying (ESA) method on steel C40.

Table 2. Parameters of the crystal lattices of the phases and quantitative phase analysis of Al-C-B coatings on steel C40.

\begin{tabular}{|c|c|c|c|}
\hline Discharge Energy, J & Phase & Parameters of Crystal Lattices, $a, \mathrm{~nm}$ & Phase Content, \% (mass.) \\
\hline \multirow{2}{*}{0.13} & FCC solid solution & 36.189 & 8 \\
\hline & BCC solid solution & 28.651 & 92 \\
\hline \multirow{2}{*}{0.55} & BCC solid solution & 36.189 & 8 \\
\hline & BCC solid solution & 28.651 & 92 \\
\hline \multirow{9}{*}{4.9} & & $a=153.920$ & \\
\hline & Fo, $A l_{1}$ & $b=81.779$ & 10 \\
\hline & $\mathrm{Fe}_{4} \mathrm{Al}_{13}$ & $c=124.914$ & \\
\hline & & $\beta=107.3709$ & \\
\hline & & $a=50.818$ & \\
\hline & $\mathrm{Fe}_{3}(\mathrm{CB})$ & $b=67.791$ & 43 \\
\hline & & $c=45.170$ & \\
\hline & FCC solid solution & $a=36.209$ & 14 \\
\hline & BCC solid solution & $a=28.699$ & 33 \\
\hline
\end{tabular}


In addition to the solid solutions of BCC and FCC with the crystal lattice parameters altered upward (Table 2), the coatings obtained at $\mathrm{W}_{\mathrm{p}}=4.9 \mathrm{~J}$ are characterised by the presence of $\mathrm{Fe}_{4} \mathrm{Al}_{13}$ intermetallic compounds and $\mathrm{Fe}_{3}(\mathrm{CB})$ borocementite. The formation of those phases contributes to significantly strengthening and increasing the microhardness of the surface layer up to $12350 \mathrm{MPa}$ (Table 1).

The X-ray microanalysis of the obtained coatings indicates that during the electrospark alloying process, the surface layers are saturated with aluminium, boron, and carbon. With increasing discharge energy, the diffusion zone of these elements increases. So, at the ESA process with a minimum investigated discharge energy of $0.13 \mathrm{~J}$ for steel C40, the diffusion zone is about $12 \mu \mathrm{m}$.

When replacing a substrate made of steel C40 with the same one but of steel C22, as a result of processing with the use of the ESA method, an increase in the thickness of the surface layer accompanied by a slight decrease in microhardness is observed (Figures 2 and 4). Obviously, the influence of carbon content in material (steel C22 contains about $0.2 \%$ carbon, steel $\mathrm{C} 40$ about $0.4 \%$ ) is due to the formation of a multiphase hardening structure. Figure 5 shows microstructure of the Al-C-B and Figure 6 shows the results of electron microscopic studies of Al-C-B coatings on steel C22. At $W_{p}=0.13 \mathrm{~J}$, thin and discontinuous layers are formed. With increasing discharge energy, the thickness of the coatings and their continuity increases.

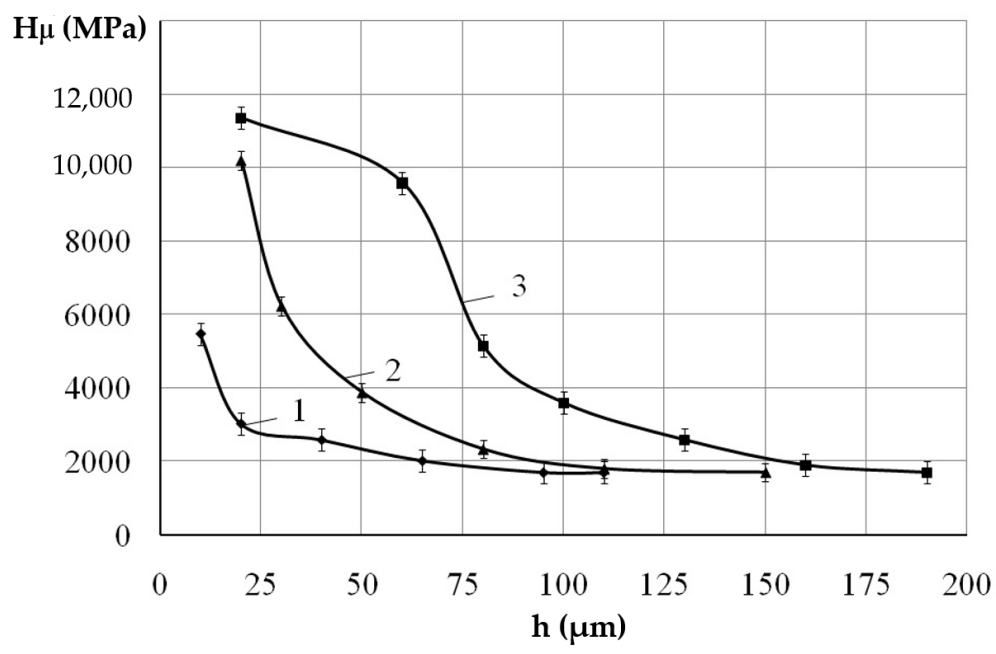

Figure 4. Microhardness distribution for Al-C-B coatings on steel C22: (1) $\mathrm{W}_{\mathrm{p}}=0.13 \mathrm{~J}$; (2) $\mathrm{W}_{\mathrm{p}}=0.55 \mathrm{~J}$; (3) $\mathrm{W}_{\mathrm{p}}=4.9 \mathrm{~J}$.

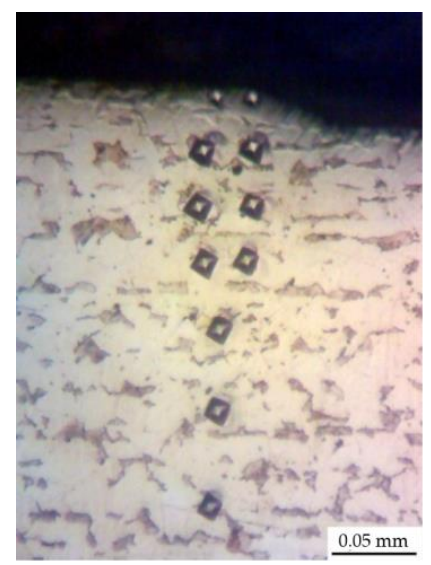

(a)

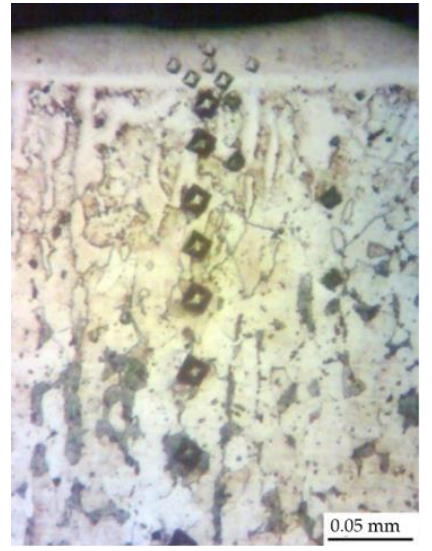

(b)

Figure 5. Microstructures for Al-C-B coatings on steel C22: (a) $\mathrm{W}_{\mathrm{p}}=0.55 \mathrm{~J}$; (b) $\mathrm{W}_{\mathrm{p}}=4.9 \mathrm{~J}$. 


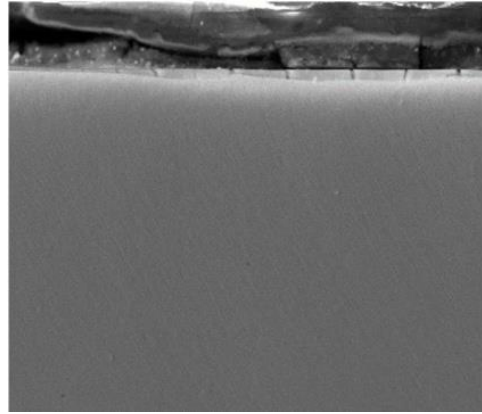

(a)

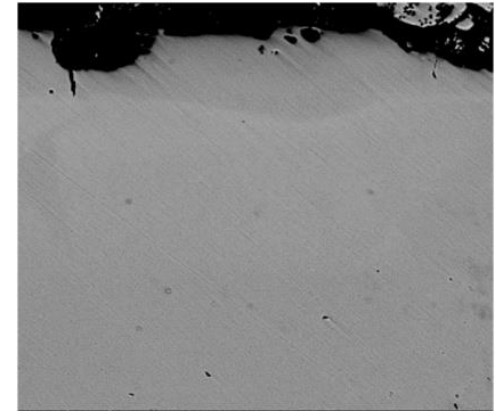

(b)

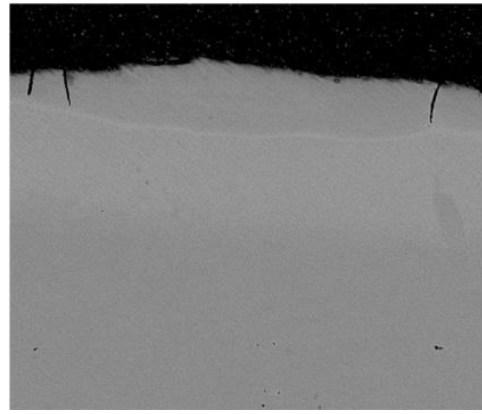

(c)

Figure 6. Structures of the surface Al-C-B coatings on steel C22 obtained by the ESA method: $(\mathbf{a}) \mathrm{W}_{\mathrm{p}}=0.13 \mathrm{~J}(\mathrm{mag}$. $2400 \times)$; (b) $\mathrm{W}_{\mathrm{p}}=0.55 \mathrm{~J}(\mathrm{mag} .2400 \times) ;\left(\right.$ c) $\mathrm{W}_{\mathrm{p}}=4.9 \mathrm{~J}($ mag. $1200 \times)$.

It should be noted that with increasing discharge energy, the diffusion zone of $\mathrm{Al}$, $\mathrm{C}$, and $\mathrm{B}$ also increases in the coating. So, at $\mathrm{W}_{\mathrm{p}}=0.13 \mathrm{~J}$, this zone is $5-7 \mu \mathrm{m}$, while at $\mathrm{W}_{\mathrm{p}}=4.9 \mathrm{~J}$ it is $23-25 \mu \mathrm{m}$ (Figure 7 ). Carbon and aluminium diffuse to a greater extent far below the surface.

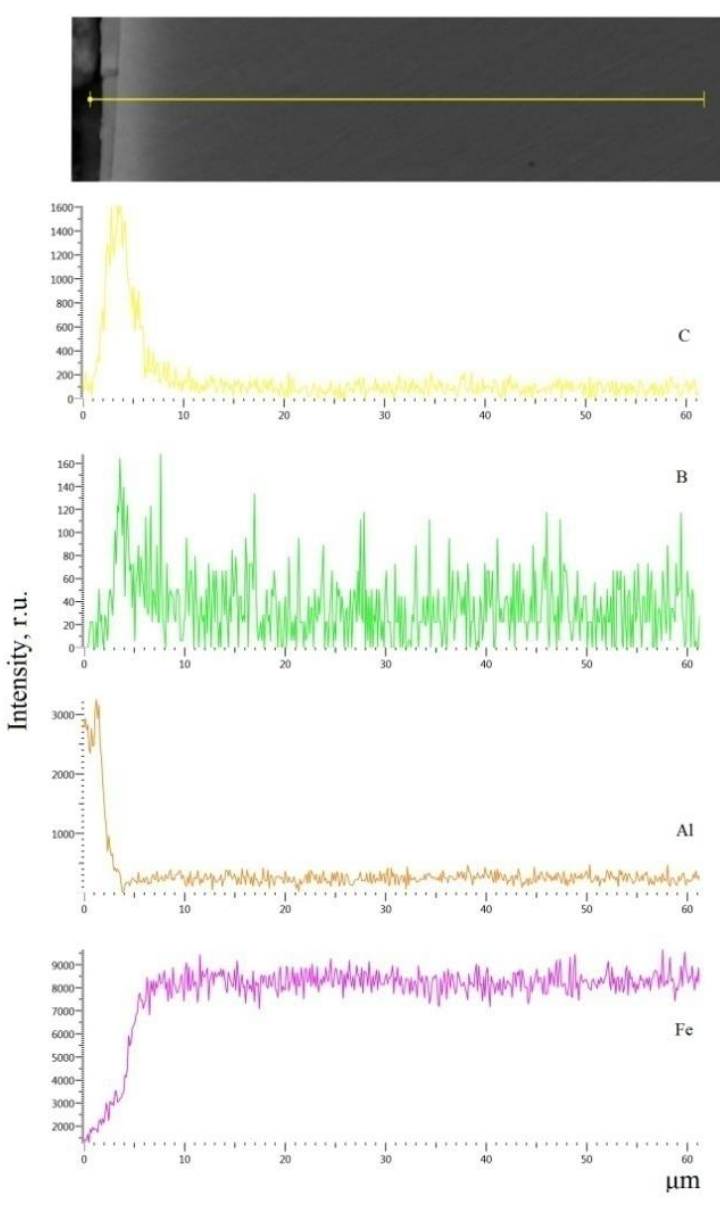

(a)
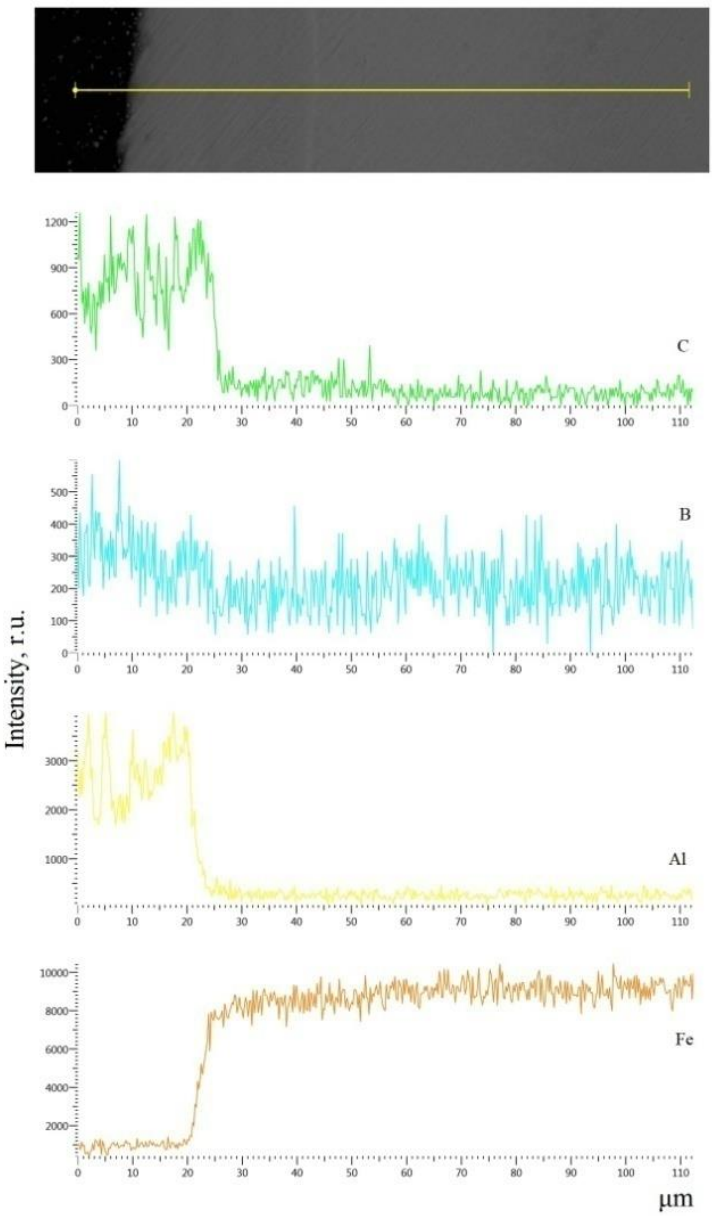

(b)

Figure 7. Distribution of the elements (carbon, boron, aluminium, and iron) in the Al-C-B coatings obtained by the ESA method with graphite electrode used on steel C22: (a) $\mathrm{W}_{\mathrm{p}}=0.13 \mathrm{~J} ;$ (b) $\mathrm{W}_{\mathrm{p}}=4.9 \mathrm{~J}$. 


\section{Kinetics of the Formation of Al-C-B Coatings by the ESA Method}

As previously noted [32], the ESA process is ensured by a self-consistent change in the concentration of atoms $n$, stress $\sigma$, and substrate temperature $T$ measured by ambient temperature. The process of increasing the thickness of the forming coating is conditioned by the fact that temperature $\mathrm{T}$ increases due to the formation of an excess of the atomised substance atoms. This enhances the evaporation of the precipitated substance atoms due to an increase in the absolute value of the internal stress $\sigma<0$, which compensates for the initial concentration. The evolution equations of these quantities contain a dissipative contribution and terms representing the positive and negative feedbacks shown in the modified dimensionless Lorentz system [33]:

$$
\begin{gathered}
\tau \cdot n^{\prime}=-\mathrm{n} \cdot \sigma+\varepsilon_{\mathrm{n}} \cdot \xi_{,} \\
\tau_{\mathrm{T}} \cdot \mathrm{T}^{\prime}=-\mathrm{T}+\mathrm{n} \cdot \sigma+\varepsilon_{\mathrm{T}} \cdot \eta, \\
\tau_{\sigma} \cdot \sigma^{\prime}=\left(\sigma_{0}-\sigma\right)-\mathrm{n} \cdot \mathrm{T},
\end{gathered}
$$

where in:

$\varepsilon_{\mathrm{n}}, \varepsilon_{\mathrm{T}}$-concentration fluctuation amplitude and temperature fluctuation amplitude;

$\xi, \eta$-independent white noise;

$\tau_{\mathrm{T}}$-temperature relaxation time;

$\tau_{\sigma}$-stress relaxation time;

$\tau$-concentration relaxation time;

where the relaxation time is defined as

$$
\xi=\xi(t) ; \quad\langle\xi(t)\rangle=0 ; \quad\left\langle\xi(t) \xi\left(t^{\prime}\right)\right\rangle=\delta\left(t-t^{\prime}\right)
$$

Based on the phase plane method, we will discuss the evolution of the system in more detail assuming, in turn, that one of the degrees of freedom has the highest relaxation rate [34].

We will first consider the behaviour of the system at rapid stress relaxation, $\tau_{\sigma}<<\tau_{\mathrm{T}}=\tau$ :

$$
\begin{gathered}
\tau \cdot n^{\prime}=-n+\sigma_{0}-n \cdot T+\varepsilon_{n} \cdot \xi, \\
\tau_{T} \cdot T^{\prime}=-T+n \cdot\left(\sigma_{0}-n \cdot T\right)+\varepsilon_{T} \cdot \eta
\end{gathered}
$$

In the phase portraits (Figures 8-10), there can be observed only the attracting part (unit), which corresponds to the steady state characterising the diffusion process.

At low values of internal stress and concentration, a single state is realised corresponding to the stationary mode of condensation. Comparison of phase-plane portraits corresponding to different ratios of relaxation times shows that the fastest evolution of the system occurs along the axis corresponding to the shortest of these times. In this case, near the stationary points, either a zone of slow evolution (the channel of a large river), or a spiral zone, on which a non-monotonic mode of condensation is realised, is observed. A study of the conditions for the realisation of this regime shows that it is favoured by an increase in the temperature relaxation time. Thus, phase-plane portraits with the specified range of temperature, stress, and concentration changes make it possible to form a specialist's idea of the duration of the formation of the diffusion layer and the parameters that affect the appearance of new layers. 


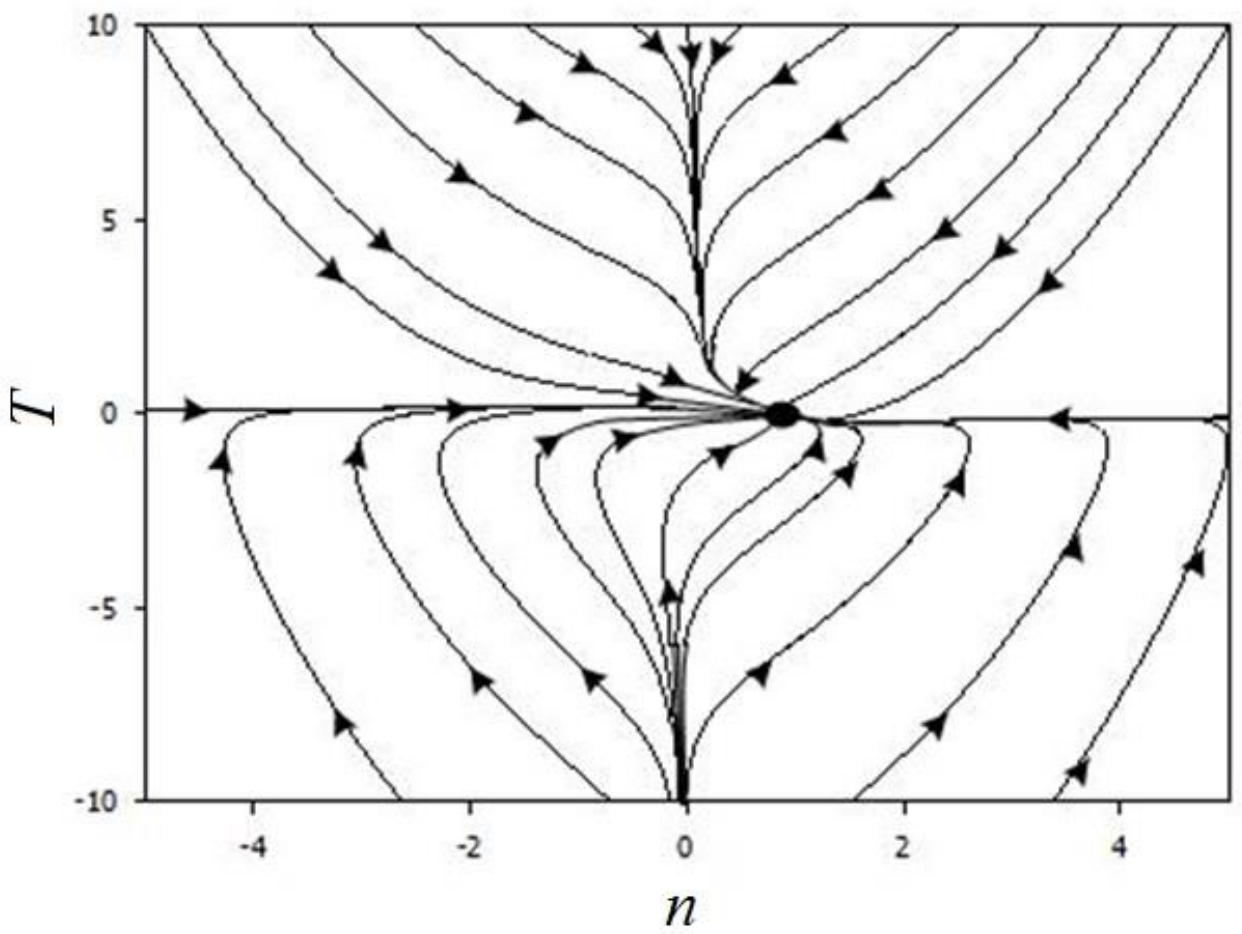

Figure 8. Phase portrait at $\tau_{\sigma}<<\tau_{T}=\tau, \sigma_{0}=0.5, \tau_{T} / \tau=1, \varepsilon_{n}=0.5, \xi=0.1, \varepsilon_{T}=0.01$, and $\eta=0.05$.

Fast relaxation of temperature, $\tau_{\mathrm{T}}<<\tau_{\sigma}=\tau$ :

$$
\begin{gathered}
\tau \cdot n^{\prime}=-n+\sigma+\varepsilon_{n} \cdot \xi, \\
\tau_{\sigma} \cdot \sigma^{\prime}=\left(\sigma_{0}-\sigma\right)-n \cdot\left(n \cdot \sigma+\varepsilon_{T} \cdot \eta\right)
\end{gathered}
$$

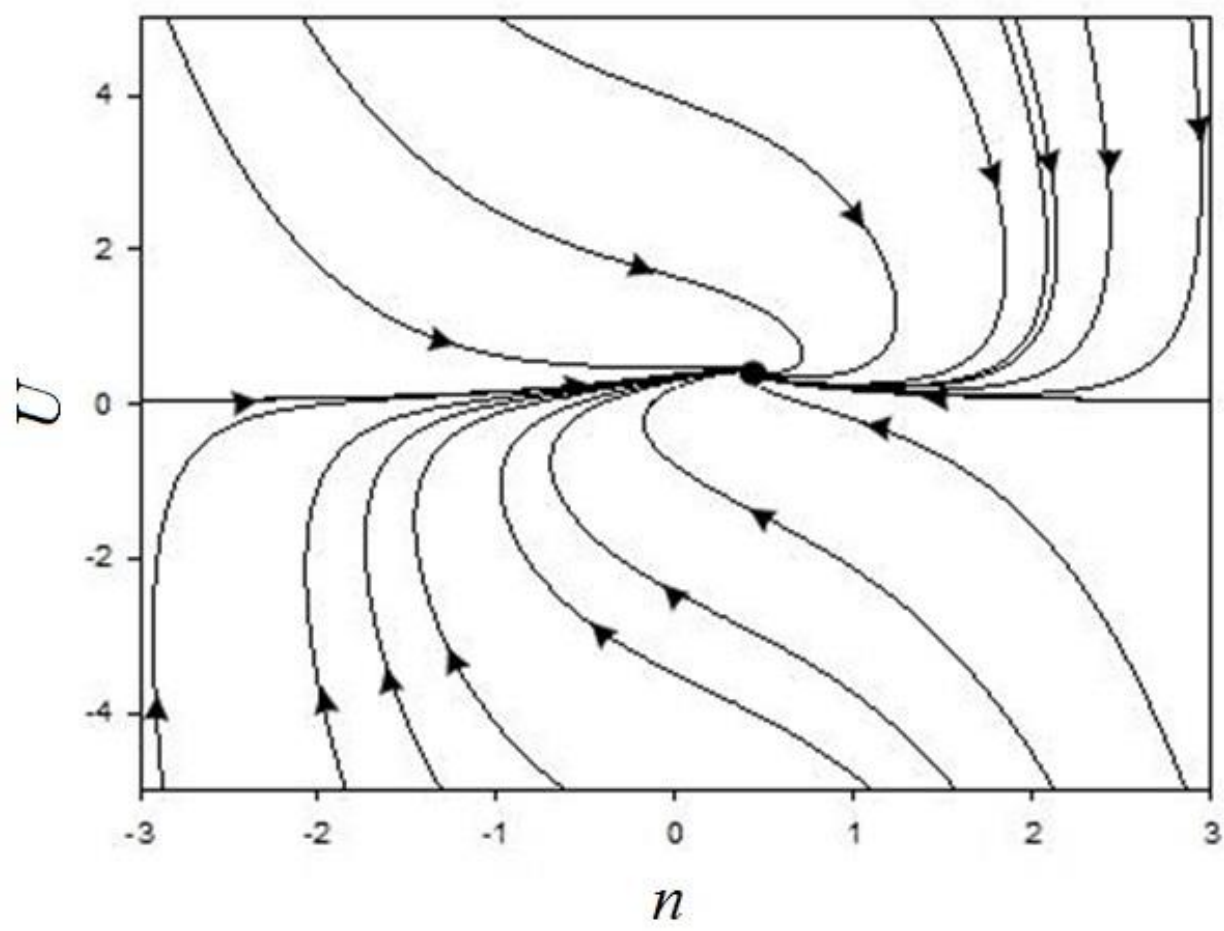

Figure 9. Phase portrait at $\tau_{\mathrm{T}}<<\tau_{\sigma}=\tau, \sigma_{0}=0.5, \tau_{\sigma} / \tau=1, \varepsilon_{\mathrm{n}}=0.5, \xi=0.1, \varepsilon_{\mathrm{T}}=0.01$, and $\eta=0.05$. 
Fast relaxation of concentration, $\tau<<\tau_{\sigma}=\tau_{\mathrm{T}}$ :

$$
\begin{gathered}
\tau_{\mathrm{T}} \cdot \mathrm{T}^{\prime}=-\mathrm{T}+\sigma \cdot\left(\sigma+\varepsilon_{\mathrm{n}} \cdot \xi\right)+\varepsilon_{\mathrm{T}} \cdot \eta, \\
\tau_{\sigma} \cdot \sigma^{\prime}=\left(\sigma_{0}-\sigma\right)-\mathrm{T} \cdot\left(\sigma+\varepsilon_{\mathrm{n}} \cdot \eta\right)
\end{gathered}
$$

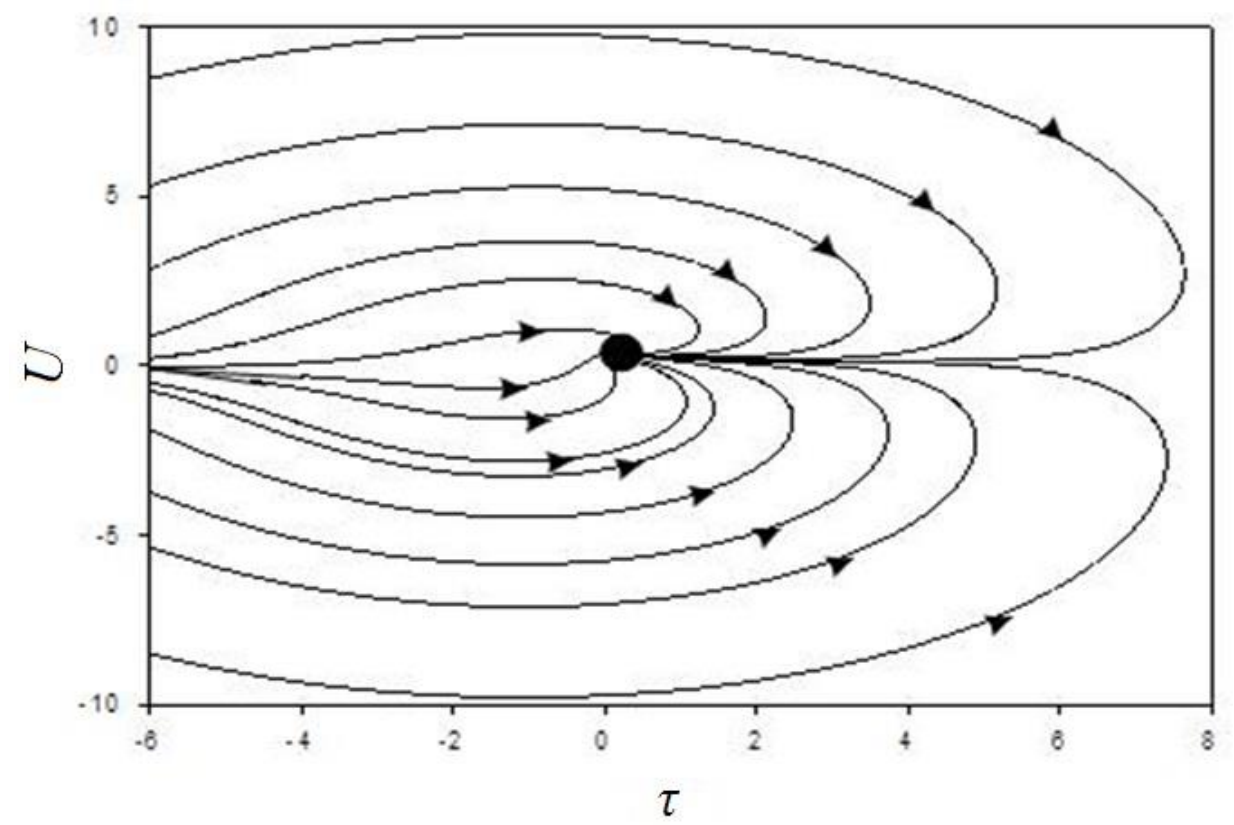

Figure 10. Phase portrait at $\tau<<\tau_{\sigma}=\tau_{\mathrm{T}}, \sigma_{0}=0.5, \tau_{\sigma} / \tau_{\mathrm{T}}=1, \varepsilon_{\mathrm{n}}=0.5, \xi=0.1, \varepsilon_{\mathrm{T}}=0.01$, and $\eta=0.05$.

\section{Summary and Conclusions}

1. The possibility of applying the ESA method to obtain boron-containing coatings characterised by increased hardness and wear resistance was considered.

2. The microstructural analysis of the Al-C-B coatings showed that the surface layer consists of several zones, the number and parameters of which are determined by the energy conditions of the ESA process. Durametric studies showed that with an increase in the discharge energy influence, the microhardness values of both the upper strengthened layer and the diffusion zone increase.

3. The results of $X$-ray diffraction analysis indicate that the discharge energies of 0.13 and $0.55 \mathrm{~J}$, the phase composition of the coating is represented by solid solutions of BCC (body-centred cubic lattice) and FCC (face-centred cubic lattice) with the parameter of $a=28.651 \mathrm{~nm}$ and $36.189 \mathrm{~nm}$, respectively. In addition to the solid solutions of BCC and FCC, the coatings obtained at $\mathrm{W}_{\mathrm{p}}=4.9 \mathrm{~J}$ are characterised by the presence of intermetallics $\mathrm{Fe}_{4} \mathrm{Al}_{13}$ and borocementite $\mathrm{Fe}_{3}(\mathrm{CB})$, with the altered upward parameters of the crystal lattice. The formation of these phases contributes to a significant strengthening and increasing of the microhardness of the surface layer up to $12,350 \mathrm{MPa}$.

4. The X-ray microanalysis of the obtained coatings indicates that during the electrospark alloying process, the surface layers are saturated with aluminium, boron, and carbon. With increasing discharge energy, the diffusion zone increases.

5. There were simulated phase portraits in the MathCAD environment. The kinetics of the layer formation processes were investigated at different ratios of the relaxation time of the sprayed material, the internal stress, and the temperature of the substrate. It was shown that near the stationary points in the phase portraits, one can see either a slowing down of the evolution or a spiral twisting of the diffusion process particle. Having analysed an image, a specialist can possess information about the limits for changing the values of the temperature or atom concentrations on the surface and thus be enabled to control the process of obtaining boron-containing coatings of the Al-C-B system by the ESA method. 
Author Contributions: Conceptualization, O.P.G., B.A., and V.B.T.; methodology, B.A., V.B.T., and O.P.G.; software, O.M.M., P.K., T.I.Z., and I.K.; validation, O.M.M. and P.K.; formal analysis, O.P.G and V.B.T.; investigation, O.P.G., V.B.T., O.M.M., P.K., and T.I.Z.; resources, O.M.M., T.I.Z., and I.K.; data curation, B.A., O.P.G., and V.B.T.; writing-original draft preparation, O.P.G. and V.B.T.; writing-review and editing, O.M.M., P.K., T.I.Z., and I.K.; visualization, O.M.M., P.K., T.I.Z., and I.K.; supervision, B.A.; project administration, B.A.; funding acquisition, B.A. and P.K. All authors have read and agreed to the published version of the manuscript.

Funding: This research received no external funding.

Institutional Review Board Statement: Not applicable.

Informed Consent Statement: Not applicable.

Data Availability Statement: Data sharing not applicable.

Conflicts of Interest: The authors declare no conflict of interest.

\section{References}

1. Mayer, E. Mechanical Seals; Butterworth-Heinemann: Oxford, UK, 2013.

2. Tarel'nik, V.B.; Martsinkovskii, V.S.; Zhukov, A.N. Increase in the Reliability and Durability of Metal Impulse End Seals. Chem. Pet. Eng. 2017, 53, 114-120. [CrossRef]

3. Keddam, M.; Chegroune, R.; Kulka, M.; Makuch, N.; Panfil, D.; Siwak, P.; Taktak, S. Characterization, Tribological and Mechanical Properties of Plasma Paste Borided AISI 316 Steel. Trans. Indian Inst. Met. 2018, 71, 79-90. [CrossRef]

4. Pischov, M.N.; Belskiy, S.E.; Andreykovets, E.P.; Zhishkevich, M.M. Effect of complex borating on the characteristics of hardening gears in bench tests. Cast. Metall. 2015, 107-112.

5. Jain, V.; Sundararajan, G. Influence of the pack thickness of the boronizing mixture on the boriding of steel. Surf. Coat. Technol. 2002, 149, 21-26. [CrossRef]

6. Joshi, A.A.; Hosmani, S.S. Pack-Boronizing of AISI 4140 Steel: Boronizing Mechanism and the Role of Container Design. Mater. Manuf. Process. 2014, 29, 1062-1072. [CrossRef]

7. Campos-Silva, I.; Ortiz-Domínguez, M.; Tapia-Quintero, C.; Rodríguez-Castro, G.; Jiménez-Reyes, M.Y.; Chávez-Gutiérrez, E. Kinetics and Boron Diffusion in the $\mathrm{FeB} / \mathrm{Fe}_{2} \mathrm{~B}$ Layers Formed at the Surface of Borided High-Alloy Steel. J. Mater. Eng. Perform. 2012, 21, 1714-1723. [CrossRef]

8. Gunes, I.; Yıld1z, I. Investigation of Adhesion and Tribological Behavior of Borided AISI 310 Stainless Steel. Matéria 2016, 21, 79-90. [CrossRef]

9. Builov, V.N.; Lyulyakov, I.V. Investigation into the Process of Electrolysis Borating of Steel Parts. Surf. Eng. Appl. Electrochem. 2018, 54, 338-344. [CrossRef]

10. Carrera-Espinoza, R.; Figueroa-Lopez, U.; Martínez-Trinidad, J.; Campos-Silva, I.; Hernandez-Sanchez, E.; Motallebzadeh, A. Tribological behavior of borided AISI 1018 steel under linear reciprocating sliding conditions. Wear 2016, 362, 1-7. [CrossRef]

11. Sizov, I.G. Otsenka khrupkosti boridnykh sloyev posle elektronno-luchevogo borirovaniya (Evaluation of fragility of bored layers after electronic beam boring). Sovrem. Nauk. Tekhnologii Mod. High Technol. 2005, 11. Available online: https://elibrary.ru/item. asp?id=11524022 (accessed on 20 January 2021). (In Russian)

12. Rotshtein, V.P.; Proskurovsky, D.I.; Ozur, G.E.; Ivanov, Y.F.; Markov, A.B. Surface modification and alloying of metallic materials with low-energy high-current electron beams. Surf. Coat. Technol. 2004, 180, 377-381. [CrossRef]

13. Yun, E.; Lee, S. Improvement of hardness and wear resistance in stainless-steelbased surface composites fabricated by high-energy electron beam irradiation. Surf. Coat. Technol. 2006, 200, 3478-3485. [CrossRef]

14. Santana, D.A.; Koga, G.Y.; Wolf, W.; Bataev, I.A.; Ruktuev, A.A.; Bolfarini, C.; Kiminami, C.S.; Botta, W.J.; Jorge, A.M., Jr. Wear-resistant boride reinforced steel coatings produced by non-vacuum electron beam cladding. Surf. Coat. Technol. 2020, 386, 125466. [CrossRef]

15. Chernega, S.M.; Zaulichnyi, Y.V. Effect of Chromium on the Structure and Properties of Boride Diffusion Coatings. Powder Metall. Met. Ceram. 2000, 39, 594-598. [CrossRef]

16. Chernega, S.M.; Poliakov, I.A.; Krasovskiy, M.O. Formation of Complex Diffusion Boride Layers on Metastable Austenitic Nitrogen-Containing Chromium-Manganese Steels in Conditions of Action of an External Magnetic Field. Metallofiz. Noveishie Tekhnol. 2016, 38, 1479-1495. [CrossRef]

17. Kulka, M.; Makuch, N.; Pertek, A. Microstructure and properties of laser-borided 41Cr4 steel. Opt. Laser Technol. 2013, 45, 308-318. [CrossRef]

18. Sashank, S.; Dinesh Babu, P.; Marimuthu, P. Experimental studies of laser borided low alloy steel and optimization of parameters using response surface methodology. Surf. Coat. Technol. 2019, 363, 255-264. [CrossRef]

19. Bataev, I.A.; Bataev, A.A.; Golkovsky, M.G.; Teplykh, A.Y.; Burov, V.G.; Veselov, S.V. Non-vacuum electron-beam boriding of low-carbon steel. Surf. Coat. Technol. 2012, 207, 245-253. [CrossRef] 
20. Kukhar, V.V.; Grushko, A.V.; Vishtak, I.V. Shape Indexes for Dieless Forming of the Elongated Forgings with Sharpened End by Tensile Drawing with Rupture. Solid State Phenom. 2018, 284, 408-415. [CrossRef]

21. Astafiev, G.I.; Fainshmidt, E.M.; Pegashkin, V.F.; Pilipenko, V.V.; Andriyanov, A.V.; Pilipenko, V.F.; Khomenko, A.Y. Sposob Elektroerozionnogo Borirovaniya Poverkhnosti Detail iz Stali i Chuguna (Method of Electroerosive Boriding of a Surface of a Part Made of Steel and Cast Iron). Russian Patent 2421307 C2 RU, 8 October 2008. (In Russian). Available online: https: / / elibrary.ru/item.asp?id=37747807 (accessed on 20 January 2021).

22. Tarelnyk, V.B.; Gaponova, O.P.; Konoplyanchenko, Y.V.; Yevtushenko, N.S.; Herasymenko, V.O. The Analysis of a Structural State of Surface Layer after Electroerosive Alloying. II. Features of Formation of Electroerosive Coatings on Special Steels and Alloys by Hard Wear-Resistant and Soft Antifriction Materials. Metallofiz. Noveishie Tekhnol. 2018, 40, 795-815. [CrossRef]

23. Tarelnyk, V.; Martsynkovskyy, V.; Gaponova, O.; Konoplianchenko, I.; Belous, A.; Gerasimenko, V.; Zakharov, M. New method for strengthening surfaces of heat treated steel parts. In Proceedings of the 15th International Scientific and Engineering Conference Hermetic Sealing, Vibration Reliability and Ecological Safety of Pump and Compressor Machinery (HERVICON + PUMPS 2017), Sumy, Ukraine, 5-8 September 2017; Volume 233, p. 012048.

24. Tarelnyk, V.; Martsynkovskyy, V.; Gaponova, O.; Konoplianchenko, I.; Dovzyk, M.; Tarelnyk, N.; Gorovoy, S. New sulphiding method for steel and cast iron parts. In Proceedings of the 15th International Scientific and Engineering Conference Hermetic Sealing, Vibration Reliability and Ecological Safety of Pump and Compressor Machinery (HERVICON + PUMPS 2017), Sumy, Ukraine, 5-8 September 2017; Volume 233, p. 012049.

25. Martsynkovskyy, V.; Tarelnyk, V.; Konoplianchenko, I.; Gaponova, O.; Dumanchuk, M. Technology Support for Protecting Contacting Surfaces of Half-Coupling-Shaft Press Joints Against Fretting Wear. In Advances in Design, Simulation and Manufacturing II, Proceedings of the 2nd International Conference on Design, Simulation, Manufacturing: The Innovation Exchange, DSMIE 2019, Lutsk, Ukraine, 11-14 June 2019; Springer: Cham, Switzerland, 2019; pp. 216-225.

26. Myslyvchenko, O.M.; Gaponova, O.P.; Tarelnyk, V.B.; Krapivka, M.O. The Structure Formation and Hardness of High-Entropy Alloy Coatings Obtained by Electrospark Deposition. Powder Metall. Met. Ceram. 2020, 59, 201-208. [CrossRef]

27. Korotaev, D.N. Tekhnologicheskiye Vozmozhnosti Formirovaniya Iznosostoykikh Nanostruktur Elektroiskrovym Legirovaniyem (Technological Possibilities of Forming Wear-Resistant Nanostructures by Electrospark Alloying); SibADI: Omsk, Russia, 2009. (In Russian)

28. Kheifets, M.L. Puti povysheniya effektivnosti protsessov formirovaniya poverkhnostey s pozitsiyey sinergetiki. (Ways to improve the efficiency of the processes of forming surfaces with a synergetic position). Vestn. Mashinostroyeniya Mech. Eng. Bull. 1994, 2. Available online: https:/ / www.elibrary.ru/item.asp?id=37187249 (accessed on 20 January 2021). (In Russian)

29. Kabaldin, Y.G. Sinergetika. Informatsionnyye Modeli Samosborki Nanosistem i Nanostrukturirovaniya Materialov pri Vneshnem Mekhanicheskom Vozdeystvii (Synergetics. Information Models of Self-Assembly of Nanosystems and Nanostructuring of Materials under External Mechanical Stress); KnAGTU: Komsomolsk-on-Amur, Russia, 2007. (In Russian)

30. Brower, A.V.; Dyachenko, L.D. Uprochnyayushchiye Tekhnologi i Pokrytiya Hardening Technologies and Coatings. 2007. Available online: http:/ / www.mashin.ru/files/u_307.pdf (accessed on 20 January 2021). (In Russian)

31. Kim, V.A. Samoorganizatsiya $v$ Protsessakh Uprochneniya, Treniya i Iznashivaniya Rezhushchego Instrumenta (Self-Organization in the Processes of Strengthening, Friction and Wear of Cutting Tool); Dalnauka: Vladivostok, Russia, 2001. (In Russian)

32. Tsallis, C. Lecture Notes in Physics; Abe, S., Okamoto, Y., Eds.; Springer: Berlin/Heidelberg, Germany, 2001.

33. Lorenz, E.N. Deterministic nonperiodic flow. J. Atmos. Sci. 1963, 20, 130-141. [CrossRef]

34. Zhilenko, T.I.; Yushchenko, O.V. Static description of a stochastic condensation system. Tech. Phys. 2013, 58, 1558-1562. [CrossRef] 